\title{
A Comprehensive Review of COVID-19 Treatment
}

\author{
Zeinab Mohseni Afshar', Arefeh Babazadeh², Mostafa Javanian², Mohammad Barary³, \\ Veneela Krishna Rekha Vasigala ${ }^{4}$, Soheil Ebrahimpour ${ }^{2}$ \\ ${ }^{1}$ Clinical Research Development Center, Imam Reza Hospital, Kermanshah University of Medical Sciences, \\ Kermanshah, Iran \\ ${ }^{2}$ Infectious Diseases and Tropical Medicine Research Center, Health Research Institute, \\ Babol University of Medical Sciences, Babol, Iran \\ ${ }^{3}$ Student Research Committee, Babol University of Medical Sciences, Babol, Iran \\ ${ }^{4}$ Rangaraya Medical College, NTR University of Health Sciences, Kakinada, India
}

\section{SUMMARY}

Severe acute respiratory syndrome coronavirus 2 (SARS-CoV-2) is the virus strain that caused coronavirus disease 2019 (COVID-19). This novel coronavirus is an emerging global health threat. It caused approximately 140 million confirmed cases, with about 3 million deaths worldwide until April 18, 2021. Although there are two approved medications for this disease, remdesivir and dexamethasone, numerous studies are underway to investigate more therapeutic options. However, so far, most treatments have been supportive, and the clinical efficacy of the suggested drugs is still under consideration. The purpose of this review is to summarize the ongoing treatments, such as several antivirals, convalescent plasma transfusion, and adjunctive medications, with the intent of serving as a clinical guide for the physician and a resource for further evaluations in various clinical trials.

Key words: COVID-19, SARS-CoV-2, therapeutics, antiviral agents, COVID-19 serotherapy

Corresponding author:

Soheil Ebrahimpour

e-mail: drsoheil1503@yahoo.com 


\section{INTRODUCTION}

Coronaviruses (CoVs), a member of the Coronaviridae family, are enveloped positive-sense RNA viruses that can cause severe infectious diseases in humans and animals $(1,2)$. They are divided into four genera: alpha, beta, delta, and gamma coronaviruses (3). So far, beta coronaviruses, such as severe acute respiratory syndrome coronavirus (SARS-CoV) and Middle East respiratory syndrome coronavirus (MERS-CoV) have caused significant morbidity and mortality (4 - 6). At the end of December 2019, an unknown pathogen in Wuhan, China, began to cause life-threatening pneumonia, which was subsequently named severe acute respiratory syndrome coronavirus 2 (SARS-CoV-2), or 2019 novel coronavirus (2019-nCoV) causing coronavirus disease 2019 (COVID-19 (7). Subsequent research has shown that the SARS-CoV-2 genome is about $89 \%$ and $80 \%$ identity with bat SARS-like-CoVZXC21 and human SARS-CoV, respectively (8). Evidence suggests that COVID-19, similar to SARS-CoV and MERS-CoV, is a zoonotic coronavirus. There are approximately 140 million confirmed COVID-19 cases worldwide, with about 3 million deaths (9). Hundreds of healthcare workers were infected with this virus after close contact with infected cases, indicating interpersonal transmission of the virus.

In this review, we aim to summarize the current evidence on the promising treatments against COVID-19. To this date, only two medications, remdesivir and dexamethasone, were approved for this disease, and the efficacy of several other promising therapeutic agents is still under investigation. Nevertheless, most of the current therapeutic options are supportive care. It is noteworthy that previous studies on antiviral agents effective on SARS-CoV and MERS-CoV are the mainstay of present preclinical and clinical evidence on anti-SARS-CoV-2 medications. However, it is unclear how well these treatments can be effective against COVID-19.

Coronaviruses use their spike glycoproteins (S) to bind host cell receptors, mediate membrane fusion, and viral entry into the cells. Spike glycoprotein is trimeric, and each monomer consists of S1 and S2 subunits, mediating attachment and membrane fusion, respectively (10). The fusion process in coronaviruses is similar to human immunodeficiency virus type I (HIV-1). Targeting the spike proteins by developing therapeutic antibodies to treat SARS-CoV is an area of active investigation.
As the similarity of spike proteins among various coronaviruses is relatively high, the efficacy of antiSARS-CoV antibodies against SARS-CoV-2 is being investigated (11). Moreover, most neutralizing antibodies, such as monoclonal antibodies (mAbs), which are biotherapeutics for passive immunotherapy, may be helpful for therapeutic purposes to fight against viral infection like COVID-19.

Antiretroviral protease inhibitors are being investigated as therapeutic targets for COVID-19. Studies have shown that atazanavir, efavirenz, ritonavir, and dolutegravir, which are antiretroviral medications for treating and preventing HIV, show inhibitory effects against the COVID-19 3c-like protease (12). Other agents, such as lopinavir, ritonavir, and darunavir, also target viral proteases. Therefore, Kaletra, lopinavir/ritonavir combination (LPV/RTV), was thought to be effective in COVID-19 treatment (13). Studies have shown that Kaletra-containing regimens could alleviate clinical symptoms and lower the viral load. Chinese health authorities first included Kaletra in their guidelines for coronavirus treatment. This decision was backed by some early preclinical in-vitro studies and anecdotal success in the clinic amid the lack of approved drugs. Kaletra can be administered in high-risk patients, such as the elderly, or those with underlying diseases. Despite the backing of Kaletra, the latest data from clinical studies have been disappointing in mild COVID-19 Chinese patients. Simeprevir, a protease inhibitor, explicitly targets Hepatitis $\mathrm{C}$ virus $(\mathrm{HCV})$ replication by inhibiting its NS3/4A protease. It was observed that Simeprevir could work better than Kaletra, and therefore it might be another potential drug against COVID-19 (14, 15). However, updated guidelines advise against Kaletra and other HIV protease inhibitors used in COVID-19 patients in inpatient and outpatient settings (16).

In children, interferon $\alpha-2 b$ (IFN $\alpha-2 b$ ) and Kaletra have been applied and recommended for COVID-19 infection (17). In severe patients, intravenous immunoglobulin (IVIG) at the dose of $1 \mathrm{~g} / \mathrm{kg}$ QD for two days, or $400 \mathrm{mg} / \mathrm{kg}$ QD for five days, has been suggested, but its efficacy needs further evaluation.

Several oncology drugs, such as sunitinib and erlotinib, belonging to AAK1 inhibitors, effectively inhibit viral entry and replication. Thus, they provide an opportunity to treat COVID-19 patients (18). However, these drugs may cause serious side effects. By contrast, baricitinib, a Janus kinase (JAK) in- 
hibitor and a regulator of endocytosis, has been recommended to treat this disease (19). Baricitinib's therapeutic effect could be through reducing both viral entry and inflammation in these patients.

Anti-malaria drugs, such as chloroquine, are another top candidate physicians are prescribing for the treatment of COVID-19 patients. This drug has been shown to have a broad-spectrum antiviral characteristics. It can inhibit the infection by several mechanisms, such as inhibiting viral receptors glycosylation and preventing the fusion of the virus with host cells by increasing the endosomal $\mathrm{pH}$ (20). Moreover, as this medication can act as an immunomodulator, its antiviral activity may be synergistically enhanced (21). Hydroxychloroquine, a more tolerable form of chloroquine, is also being tested because of its low price and better safety profile. Recently, the FDA strongly prohibited chloroquine and hydroxychloroquine use without strict medical supervision in a hospital or as part of a clinical trial. The agency said that without close monitoring for side effects of these drugs on COVID19 patients, they might lead to life-threatening complications. Emodin, an anthraquinone compound, has been shown to have a virucidal effect through halting the SARS-CoV-2 $\mathrm{S}$ protein and angiotensinconverting enzyme 2 gene (ACE2) interactions (22). Nevertheless, some recent trials have suggested that hydroxychloroquine could not reduce the overall mortality rate in the inpatient setting. Thus, its use is no longer recommended $(23,24)$.

Promazine, an antipsychotic of phenothiazine class, can also inhibit SARS-CoV-2 replication (25). Hence, it may be a valuable option against COVID19. Chlorpromazine and loperamide are other repurposed drugs against human coronaviruses, although no trial to date has suggested its effectiveness (26).

\section{OTHER MEDICATIONS USED FOR COVID-19}

Remdesivir (RDV), a new nucleoside analog prodrug developed initially for Ebola virus disease (EVD) treatment, was proven to inhibit MERS-CoV and SARS-CoV replication in-vitro and in-vivo by halting RNA-dependent RNA polymerase activity (20). So far, Remdesivir provided hopes of a significant breakthrough in finding cures for COVID19. Remdesivir was confirmed to lower pulmonary viral loads, promote pulmonary function, and pre- vent severe lung injury. Interestingly, in-vitro data illustrate that RDV and interferon-beta (IFN- $\beta$ ) were better antiviral agents against LPV and RTV $(22,27)$. Remdesivir is currently being investigated in multiple clinical trials and used for patients admitted in the intensive care unit (ICU) in the USA. Thus far, Remdesivir has been the sole FDA-approved antiSARS-CoV-2 medication (28).

EK1 peptide, a CoV fusion inhibitor, can inhibit several coronaviruses infection, such as three bat-SL-CoVs, MERS-CoV, and SARS-CoV. When administered intranasally, this peptide is thought to exert a potential anti-SARS-CoV-2 prophylactic and therapeutic effect (29).

Favipiravir is effective against several viruses, such as respiratory syncytial virus (RSV), SARS-CoV, MERS-CoV, COVID-19, and HCV, through halting the RNA-dependent RNA polymerase (RdRp) activity (30).

Umifenovir, sold under the brand name Arbidol (ARB), is an approved and utilized medication in Russia and China for influenza and several other respiratory viral infections prophylaxis and treatment (31). Arbidol inhibited viral entry and replication in host cells and was effective against $\mathrm{HCV}$, influenza $\mathrm{A}$ and $\mathrm{B}$ viruses, MERS-CoV, SARSCoV, and COVID-19 (32).

Nitric oxide (NO) can directly interact with superoxide, mediate bactericidal or cytotoxic reactions, and inhibit SARS-CoV replication (33). Hence, NO inhalation could be effective in patients with severe COVID-19.

Ribavirin is FDA approved for treating HCV and RSV infections which acts through viral RNA synthesis and capping inhibition (34). It has been proved to be active against COVID-19 in randomized trials (35). The FDA-approved penciclovir was originally prescribed for treating recurrent HSV, but it may act against SARS-CoV, MERS-CoV, and SARS-CoV-2 through RdRp inhibition (20, 36). Nafamostat mesylate, a synthetic serine protease inhibitor, is a potent $S$ protein-mediated membrane fusion inhibitor of MERS-CoV and approved anticoagulant therapy in Asian countries, which may be effective against COVID-19 (37).

Oseltamivir, also known as Tamiflu, is a wellknown influenza neuraminidase inhibitor (NAI) being used for COVID-19 treatment. However, no evidence supports its application (38). Also, its usage is not recommended as it may cause significant drug resistance. 
Recently, several reports of successful results of using anti-HIV and -HCV therapies against COVID-19 have been reported. For instance, protease inhibitors, such as simeprevir, and polymerase inhibitors, such as sofosbuvir (GS-7977), are among the most promising anti-SARS-CoV-2 drug candidates $(39,40)$.

Tocilizumab, sold under the brand name Actemra, is an immunosuppressive medication mainly used for rheumatoid arthritis (RA) and systemic juvenile idiopathic arthritis (SJIA) treatment. Tocilizumab effectively treated some patients with severe COVID-19 in China, which suggested a novel therapeutic strategy for this fatal infectious disease $(41,42)$. Tocilizumab exerts its therapeutic effects via competitively inhibiting the interleukin-6 (IL-6) and its receptor (IL-6R) binding (41). Therefore, some guidelines suggest using this medication in COVID19 patients admitted to the ICU within the first 24 hours of admission who require invasive or noninvasive mechanical ventilation or high-flow oxygen ( $>0.4 \mathrm{FiO} / 30 \mathrm{~L} / \mathrm{min}$ oxygen flow). Nevertheless, not enough data are presented yet to propose tocilizumab or sarilumab use as the standard treatment plan of COVID-19 patients (43).

Ivermectin is an antiparasitic drug used in limited parasitic diseases, such as onchocerciasis. However, its antiviral characteristics have not been approved by the FDA. In-vitro studies suggest that this drug exerts its effects by inhibiting intracellular transport processes, such as host importin alpha/ beta-1 nuclear transport proteins. Moreover, ivermectin, by suppressing the host's response to the virus, may enhance infection. Besides, it may interfere with SARS-CoV-2 $S$ protein and human cell membrane attachment (44). In addition to its potential general antiviral effect, this medication also has anti-inflammatory effects, which may help treat patients with COVID-19 (45). Some local guidance suggests its use in COVID-19 patients, but there is not enough data for global guidelines to advise for or against its use for COVID-19 treatment.

Some of the herbal formulations which have been proposed to have antiviral activity include Praneem (an herbal extract of neem tree), Geloy (Tinospora cordifolia) extract, Lianhuaqingwen and ShuFengJieDu Capsules, and Hing (having antimicrobial properties) (46). It is speculated that these herbals are suitable as supplements in symptomatic therapy but not for acute disease treatment.
Studies have shown that convalescent plasma treatment can significantly reduce the mortality rate of severe COVID-19 cases. A randomized, doubleblind, placebo-controlled trial concluded that early administration of high-titer convalescent plasma for SARS-CoV-2 to the elderly with the mild form of the disease reduced the progression of COVID-19 (47).

Some studies report the beneficial effect of combining corticosteroid therapy with thalidomide as an immunomodulatory and anti-inflammatory drug for the disease as the effects of thalidomide might be associated with alleviating anxiety to decrease oxygen consumption and improving nausea and vomiting (48).

Angiotensin receptor blockers (ARBs) are another newly discussed therapeutic option for treating COVID-19 patients (49). When bound to the ACE2 receptors, SARS-CoV-2 can lead to exacerbation of pneumonia through dysregulating the renin-angiotensin system (RAS). Following administration of ACE1 inhibitors (ACEIs) and angiotensin type-1 receptor blockers (ARBs), an amelioration of pulmonary inflammatory responses were observed. Since ACE2 acts as receptors for the SARS-CoV and MERS-CoV S glycoprotein, it was proposed that ARBs, such as losartan or telmisartan, would be potentially effective in controlling the spread of SARS-CoV-2 (50). It was observed that people who received these antihypertensive got lesser attacks of colds and flu-like illnesses (51). Therefore, it is speculated that ACEIs and ARBs could be COVID-19 infected patients.

Some nutrients and all immune enhancers can enhance host immunity against viruses. Vitamins are proved to have beneficial effects in preventing or lessening the damage imposed by microorganisms such as viruses. Vitamin A, an "anti-infective" vitamin, can affect viral replication inhibition (22). Therefore, this nutrient might be a promising choice for the treatment of COVID-19 patients.

Not much is known about the preventive and therapeutic effects of $B$ vitamins against this disease. Several studies have been conducted in this regard. For example, vitamin B2 (Riboflavin) effectively reduced MERS-CoV titer in humans (52). Vitamin B3 inhibited the infiltration of neutrophils into the lungs by inducing a solid anti-inflammatory response against lung injury (22). Vitamin B6 also plays a vital role in body immune function (53). Therefore, B vitamins might be fundamental options for treating 
these patients.

Vitamin C (Ascorbic acid) can alleviate immune defense by supporting immune system function. Therefore it may be helpful in the prevention and treatment of COVID-19 (54).

Vitamin D is being considered as another therapeutic option for COVID-19 (55). Its mechanism contributes to increased activation and stimulation of the maturation of immune cells.

Vitamin $\mathrm{E}$ and selenium have been suggested to be effective by their antioxidant activity. Zinc as a dietary mineral enhances innate and adaptive immunity. Besides, it may decrease COVID-19 -related symptoms like diarrhea (56). Iron deficiency has been shown to predispose humans to the development of recurrent respiratory tract infections. Therefore, iron supplements could do a favor in this entity.

Novel therapeutic approaches such as allogeneic mesenchymal stem cells are being investigated for patients with acute COVID-19 infections.

It should be considered that inappropriate antibiotic application should be avoided unless there is some evidence of secondary bacterial infection. The most common empirical antimicrobial recommended are respiratory fluoroquinolones such as moxifloxacin or levofloxacin (19). Interestingly, teicoplanin, an anti-staphylococcal antibiotic, showed efficacy in inhibiting the first stage of the MERS-CoV cycle in host cells, thus being tested further for its antiviral activity (57).

Other adjunctive medications and recommendations for COVID-19 treatment include antipyretics such as ibuprofen, carbohydrate-containing regimens, protein-rich foods, H2 receptor antagonist, and proton pump inhibitors.

As a result of COVID-19, inflammation and a prothrombotic state have been associated with fibrin, fibrin degradation products, fibrinogen, and Ddimers elevated levels. Some studies noted worse clinical outcomes in patients with elevations in these markers and evidence of COVID-19 patients with acute respiratory failure present with a severe hypercoagulability state rather than consumptive coagulopathy with a subsequent worse outcome. The guidelines recommend a prophylactic dose of lowmolecular-weight heparin (LMWH) or unfractionated heparin (UFH) to reduce deep vein thrombosis (DVT) incidence in hospitalized patients with COVID-19 (58). Therefore, these patients should not be discharged during DVT prophylaxis (59). In the outpatient setting, no data are available to support the measurement of coagulation markers, such as Ddimers, prothrombin time, platelet count, and fibrinogen. Thus, anticoagulants and antiplatelet therapies should not be initiated in these patients.

Other supportive therapies, such as oxygen therapy, bilevel positive airway pressure (BiPAP), or continuous positive airway pressure (CPAP), are beneficial and may delay or inhibit the need to undergo invasive mechanical ventilation.

\section{IMMUNE ENHANCERS IN COVID-19}

Interferon- $\alpha$ and $-\beta$ can trigger innate antiviral responses. Thus, they are effective in replication inhibition of MERS-CoV and SARS-CoV. Administration of interferon- $\alpha 2 \mathrm{~A}$ (IFN- $\alpha 2 \mathrm{~A}$ ) was introduced by the Chinese National Health Association (NHC) and included in the clinical guidelines of COVID-19. Ribavirin, a nucleoside analog with broad-spectrum antiviral effects, had raised the survival of these patients and is recommended to use in monotherapy or combination with either interferon $\alpha$ 2A (IFN- $\alpha$ 2A) or lopinavir/ ritonavir (35).

Previous experiences during the SARS-Cov outbreak suggested a potential benefit in administering high-dose intravenous immunoglobulins (IVIg) (60). Observations in Wuhan and other parts of China during the current pandemic indicated that IVIg administration before the emergence of respiratory distress and early clinical deterioration could successfully halt the disease progression and improve the clinical outcomes in these patients.

Thymosin $\alpha 1$ stimulates precursor $\mathrm{T}$ cell development in the thymus and increases the glucocorticoid-induced death resistance of the thymocyte. Some recent studies showed that thymosin $\alpha 1$ might be an immune enhancer to coronaviruses (22).

Levamisole can promote cellular immunity functions, and in combination with ascorbic acid, could improve the number and function of lymphocytes, the most vital immune cells in defending the body against SARS-CoV-2 (25).

Cyclosporine (CsA) is frequently identified for its ability to prevent allograft rejection effectively and is extensively administered following liver, kidney, and heart transplantation. It can be applied as an inhibitor of the respiratory virus such as COVID-19 $(61,62)$. 


\section{CORTICOSTEROIDS USE IN COVID-19 TREATMENT}

As the leading cause of deaths in COVID-19 patients, acute lung injury (ALI) and acute respiratory distress syndrome (ARDS) are caused in part by host immune responses. Corticosteroids have the advantage of suppressing lung inflammation and therefore prevent diffuse alveolar damage, but their harmful effect may be due to inhibition of immune responses and virus clearance (63). In other words, glucocorticoids should not be a routine mediation in the management of COVID-19 as they impair antibody responses.

However, dexamethasone with a dosage of 5$10 \mathrm{mg}$ or methylprednisolone with a dosage of $40-$ $80 \mathrm{mg}$ is recommended for intravenous administration in severely ill patients with $\mathrm{O}_{2}$ saturation $\left(\mathrm{SpO}_{2}\right)$ $<90 \%$ (64). Also, several applications of glucocorticoids have been reported in a significant number of severe cases with severe sepsis and septic shock.

Despite all of the mentioned indications, no exact clinical data exists to indicate the benefits of corticosteroids in treating respiratory infections due to RSV, influenza, MERS-CoV, SARS-CoV, and COVID-19. Some reports suggested increased mortality, secondary infection rates, and complications due to corticosteroid therapy in survivors.

In children with suspected or confirmed COVID-19 cases, corti4

costeroids can be considered in the following scenarios $(65,66)$ :

1. Rapidly deteriorating pulmonary function and the occurrence of ARDS;
2. Obvious toxic symptoms, encephalitis or encephalopathy, and hemophagocytic syndrome (HPS);

3. Septic shock;

4. Auscultation of prominent wheezing in which a short-term corticosteroid therapy may be indicated.

A recent large open-label, placebo-controlled trial has shown that dexamethasone administration caused lower mortality in patients receiving either sole oxygen therapy or invasive mechanical ventilation at randomization. Nevertheless, such promising results were not observed in patients not receiving any respiratory support $(67,68)$.

\section{CONCLUSION}

In the current review, we presented the latest advancements in the treatment of COVID-19 patients. Along with supportive therapies, no specific treatment has been introduced for COVID-19. The efficacy of some antivirals, convalescent plasma transfusion, and many similar cases need to be studied in more clinical trials.

\section{Acknowledgments}

The authors gratefully thank the Clinical Research Development Center, Imam Reza Hospital, Kermanshah University of Medical Sciences and the department of infectious diseases, Babol University of Medical Sciences.

\section{Conflict of interest}

All authors declare no conflict of interest. 


\section{References}

1. Li G, De Clercq E. Therapeutic options for the 2019 novel coronavirus (2019-nCoV). Nat Rev Drug Discov 2020;19(3):149-50 https://doi.org/10.1038/d41573-020-00016-0

2. Mohseni Afshar Z, Ebrahimpour S, Javanian M, et al. Vital role of chest $\mathrm{CT}$ in diagnosis of coronavirus disease 2019 (COVID-19). Caspian J Intern Med 2020;11:244-9.

https://europepmc.org/article/med/32874430

3. Ali SA, Baloch M, Ahmed N, Ali AA, Iqbal A. The outbreak of Coronavirus Disease 2019 (COVID19)-An emerging global health threat. J Infect Public Health 2020;13(4):644-6. https://doi.org/10.1016/j.jiph.2020.02.033

4. Lee P-I, Hsueh P-R. Emerging threats from zoonotic coronaviruses-from SARS and MERS to 2019-nCoV. J Microbiol Immunol Infect 2020 ;53(3):365-7

https://doi.org/10.1016/j.jmii.2020.02.001

5. Javanian M, Masrour-roudsari J, Bayani M, Ebrahimpour S. Coronavirus disease 2019 (COVID-19): What we need to know. Caspian J Intern Med 2020;11(2):235-6

6. Ebrahimpour S, Mohseni Afshar Z, Mohseni S, et al. Neurologic manifestations in patients with COVID-19: A case report. Caspian J Intern Med 2020;11:557-60.

7. Lai C-C, Shih T-P, Ko W-C, et al. Severe acute respiratory syndrome coronavirus 2 (SARS-CoV2) and corona virus disease-2019 (COVID-19): the epidemic and the challenges. Int $\mathrm{J}$ Antimicrob Agents $2020 ; 55(3): 105924$.

https://doi.org/10.1016/j.ijantimicag.2020.105924

8. Abduljali J, Abduljali B. Epidemiology, genome and clinical features of the pandemic SARS-CoV2: a recent view. New Microbes New Infect 2020
31;35:100672.

https://doi.org/10.1016/j.nmni.2020.100672

9. Organization WH. Coronavirus disease 2019 (COVID-19): situation report, 70. 2020

10. Walls AC, Park Y-J, Tortorici MA, et al. Structure, function, and antigenicity of the SARS-CoV-2 spike glycoprotein. Cell 2020 https://doi.org/10.1101/2020.02.19.956581

11. Kliger Y, Levanon EY. Cloaked similarity between HIV-1 and SARS-CoV suggests an anti-SARS strategy. BMC Microbiol 2003;3:20-. https://doi.org/10.1186/1471-2180-3-20

12. Rismanbaf A. Potential Treatments for COVID-19; a Narrative Literature Review. Arch Acad Emerg Med 2020 21;8(1):e29.

13. Ye X, Luo Y, Xia S, et al. Clinical efficacy of lopinavir/ritonavir in the treatment of Coronavirus disease 2019. Eur Rev Med Pharmacol Sci 2020;24(6):3390-6.

14. Lee VS, Chong WL, Sukumaran SD, et al. Computational screening and identifying binding interaction of antiviral and anti-malarial drugs: Toward the potential cure for SARS-CoV-2. Prog Drug Discover Biomed Sci 2020;3 https://doi.org/10.36877/pddbs.a0000065

15. Hosseini FS, Amanlou M. Anti-HCV and antimalaria agent, potential candidates to repurpose for coronavirus infection: Virtual screening, molecular docking, and molecular dynamics simulation study. Life Sci 2020;258:118205. https://doi.org/10.1016/j.lfs.2020.118205

16. Cao B, Wang Y, Wen D, et al. A Trial of LopinavirRitonavir in Adults Hospitalized with Severe Covid-19. N Engl J Med 2020;382(19):1787-99. https://doi.org/10.1056/NEJMc2008043 
17. Wang Y, Zhu L-Q. Pharmaceutical care recommendations for antiviral treatments in children with coronavirus disease 2019. World J Pediatr 2020:1-4 https://doi.org/10.1007/s12519-020-00353-5

18. Bekerman E, Neveu G, Shulla A, et al. Anticancer kinase inhibitors impair intracellular viral trafficking and exert broad-spectrum antiviral effects. J Clin Invest 2017;127:1338-52. https://doi.org/10.1172/JCI89857

19. Rios P, Radhakrishnan A, Antony J, et al. effectiveness and safety of antiviral or antibody treatments for coronavirus. medRxiv 2020 https://doi.org/10.1101/2020.03.19.20039008

20. Wang M, Cao R, Zhang L, et al. Remdesivir and chloroquine effectively inhibit the recently emerged novel coronavirus (2019-nCoV) in vitro. Cell Res 2020;30:269-71 https://doi.org/10.1038/s41422-020-0282-0

21. Zhang Y-p, Cui Q-y, Zhang T-m, et al Chloroquine pretreatment attenuates ischemiareperfusion injury in the brain of ob/ob diabetic mice as well as wildtype mice. Brain Res 2020;1726:146518

https://doi.org/10.1016/j.brainres.2019.146518

22. Zhang L, Liu Y. Potential interventions for novel coronavirus in China: a systemic review. J Med Virol $2020 ; 92(5): 479-90$ https://doi.org/10.1002/jmv.25707

23. Gallus S, Clavenna A, Lugo A. Does hydroxychloroquine reduce mortality for COVID19? Eur J Intern Med 2020;82:21-2. https://doi.org/10.1016/j.ejim.2020.10.015

24. Ayerbe L, Risco-Risco C, Núñez-Gil I, et al. Hydroxychloroquine treatment does not reduce COVID-19 mortality; underdosing to the wrong patients? Lancet Rheumatol 2021 https://doi.org/10.1016/S2665-9913(21)00031-X

25. Shafiee S, Davaranb S. A mini-review on the current COVID-19 treatments. Clinical Trials;21:25
26. Plaze M, Attali D, Petit AC, et al. Repurposing of chlorpromazine in COVID-19 treatment: the recovery study. L'Encephale 2020;46:S35-s9. https://doi.org/10.1016/j.encep.2020.05.006

27. Rabaan AA, Al-Ahmed SH, Sah R, et al. SARSCoV-2/COVID-19 and Advances in Developing Potential Therapeutics and Vaccines to Counter this Emerging Pandemic Virus-A Review 2020 https://doi.org/10.20944/preprints202004.0075.v1

28. Beigel JH, Tomashek KM, Dodd LE, et al. Remdesivir for the Treatment of Covid-19 - Final Report. N Engl J Med 2020;383:1813-26. https://doi.org/10.1056/NEJMc2022236

29. Panati K, Narala VR. COVID-19 Outbreak: an Update on Therapeutic Options. SN Compr Clin Med 2020:1-2.

https://doi.org/10.1007/s42399-020-00264-6

30. Chen C, Huang J, Cheng Z, et al. Favipiravir versus Arbidol for COVID-19: A Randomized Clinical Trial. medRxiv 2020 https://doi.org/10.1101/2020.03.17.20037432

31. Deng L, Li C, Zeng Q, et al. Arbidol combined with $\mathrm{LPV} / \mathrm{r}$ versus $\mathrm{LPV} / \mathrm{r}$ alone against Corona Virus Disease 2019: A retrospective cohort study. J Infect 2020;81(1):e1-e5. https://doi.org/10.1016/j.jinf.2020.03.002

32. Zhu Z, Lu Z, Xu T, et al. Arbidol monotherapy is superior to lopinavir/ritonavir in treating COVID19. J Infect 2020; 81(1):e21-e23. https://doi.org/10.1016/j.jinf.2020.03.060

33. Åkerström S, Gunalan V, Keng CT, et al. Dual effect of nitric oxide on SARS-CoV replication: viral RNA production and palmitoylation of the $S$ protein are affected. Virol 2009;395:1-9 https://doi.org/10.1016/j.virol.2009.09.007

34. Harrington PR, Fleischer R, Connelly SM, et al. Ribavirin reduces absolute lymphocyte counts in hepatitis $C$ virus-infected patients treated with interferon-free, direct-acting antiviral regimens. Clin Infect Dis 2015;61:974-7 
https://doi.org/10.1093/cid/civ419

35. Dong L, Hu S, Gao J. Discovering drugs to treat coronavirus disease 2019 (COVID-19). Drug Discover Ther 2020;14:58-60 https://doi.org/10.5582/ddt.2020.01012

36. Schmid-Wendtner M-H, Korting H. Penciclovir cream-improved topical treatment for herpes simplex infections. Skin Pharmacol Physiol 2004;17:214-8

https://doi.org/10.1159/000080214

37. Dhama K, Sharun K, Tiwari R, et al. COVID-19, an emerging coronavirus infection: advances and prospects in designing and developing vaccines, immunotherapeutics, and therapeutics. Human Vaccines Immunother 2020:1-7 https://doi.org/10.1080/21645515.2020.1735227

38. Ziaie S, Koucheck M, Miri M, et al. Review of therapeutic agents for the treatment of COVID-19. J Cel Mol Anesth 2020;5:32-6

39. Elfiky AA. Anti-HCV, nucleotide inhibitors, repurposing against COVID-19. Life Sci 2020:117477 https://doi.org/10.1016/j.lfs.2020.117477

40. Lima de Oliveira MD, Teixeira de Oliveira KM. Comparative Computational Study of SARS-CoV2 Receptors Antagonists from Already Approved Drugs. ChemRxiv 2020 https://doi.org/10.26434/chemrxiv.12044538.v1

41. Xu X, Han M, Li T, et al. Effective treatment of severe COVID-19 patients with tocilizumab. ChinaXiv 2020;202003:v1

42. Michot J-M, Albiges L, Chaput N, et al. Tocilizumab, an anti-IL6 receptor antibody, to treat Covid-19-related respiratory failure: a case report. Ann Oncol 2020

https://doi.org/10.1016/j.annonc.2020.03.300

43. Wise J. Covid-19: Arthritis drugs improve survival in intensive care patients, shows study. BMJ (Clinical research ed) 2021;372:n61. https://doi.org/10.1136/bmj.n61

44. Caly L, Druce JD, Catton MG, et al. The FDAapproved drug ivermectin inhibits the replication of SARS-CoV-2 in vitro. Antiviral Res 2020; 178:104787.

https://doi.org/10.1016/j.antiviral.2020.104787

45. Chaccour C, Casellas A, Blanco-Di Matteo A, et al. The effect of early treatment with ivermectin on viral load, symptoms and humoral response in patients with non-severe COVID-19: A pilot, double-blind, placebo-controlled, randomized clinical trial. EClin Med 2021;32:100720. https://doi.org/10.1016/j.eclinm.2020.100720

46. Chhikara BS, Rathi B, Singh J, Poonam F. Corona virus SARS-CoV-2 disease COVID-19: Infection, prevention and clinical advances of the prospective chemical drug therapeutics. Chem Biol Let 2020;7:63-72

47. Libster R, Pérez Marc G, Wappner D, et al. Early High-Titer Plasma Therapy to Prevent Severe Covid-19 in Older Adults. N Engl J Med 2021;384:610-8.

https://doi.org/10.1056/NEJMoa2033700

48. Chen C, Qi F, Shi K, et al. thalidomide combined with short-term low-dose glucocorticoid therapy for the treatment of severe COVID-19: A caseseries study. Int J Infect Dis 2021 ;103:507-513. https://doi.org/10.1016/j.ijid.2020.12.023

49. Vaduganathan M, Vardeny O, Michel T, et al. Renin-angiotensin-aldosterone system inhibitors in patients with Covid-19. N Engl J Med 2020; 382 (25): 2441-2448.

https://doi.org/10.1056/NEJMoa2008975

50. Gupta R, Ghosh A, Singh AK, Misra A. Clinical considerations for patients with diabetes in times of COVID-19 epidemic. Diabet Metab Syndr 2020;14:211

https://doi.org/10.1016/j.dsx.2020.03.002

51. Marin GH. Facts and reflections on COVID-19 and anti-hypertensives drugs. Drug Discov Ther 2020;14(2):105-6.

52. Sharma A, Tiwari V, Sowdhamini R, Campus G. Computational Search for Potential COVID-19 Drugs from FDA-Approved Drugs and Small Molecules of Natural Origin Identifies Several Antivirals and Plant Products. J Biosci 
2020;45(1):100.

https://doi.org/10.1007/s12038-020-00069-8

53. Russell B, Moss C, George G, et al. Associations between immune-suppressive and stimulating drugs and novel COVID-19-a systematic review of current evidence. ecancermedicalscience 2020;14

https://doi.org/10.3332/ecancer.2020.1022

54. Carr AC. A new clinical trial to test high-dose vitamin C in patients with COVID-19. Critical Care 2020;24:1-2

https://doi.org/10.1186/s13054-020-02851-4

55. Wimalawansa SJ. COVID-19 might be fought by 2 doses of Vitamin D (200,000-300,000 IU each)-Feb 2020. Europ J Biomed PharmSci 2020;7:432-8

56. Razzaque M. COVID-19 Pandemic: Can Maintaining Optimal Zinc Balance Enhance Host Resistance? Tohoku J Exp Med 2020;251(3):175-81. https://doi.org/10.1620/tjem.251.175

57. Baron SA, Devaux C, Colson P, et al. Teicoplanin: an alternative drug for the treatment of COVID19? Int J Antimicrobial Agents 2020: 105944 https://doi.org/10.1016/j.ijantimicag.2020.105944

58. Baccellieri D, Bertoglio L, Apruzzi L, et al. incidence of deep venous thrombosis in COVID19 hospitalized patients during the first peak of the Italian outbreak. Phlebol 2020: 268355520975592. https://doi.org/10.1177/0268355520975592

59. Kow CS, Hasan SS. Use of low-molecular-weight heparin in COVID-19 patients. J Vasc Surg Venous Lymphat Disord 2020;8:900-1. https://doi.org/10.1016/j.jvsv.2020.06.006

60. Stockman LJ, Bellamy R, Garner P. SARS: systematic review of treatment effects. PLoS med 2006;3 https://doi.org/10.1371/journal.pmed.0030343

61. Di Lernia V. Antipsoriatic treatments during COVID-19 outbreak. Dermatologic Therapy 2020

62. Banerjee D, Popoola J, Shah S, et al. COVID-19 infection in kidney transplant recipients. Kidney Int 2020 ;97(6):1076-82. https://doi.org/10.1016/j.kint.2020.03.018

63. Russell CD, Millar JE, Baillie JK. Clinical evidence does not support corticosteroid treatment for 2019-nCoV lung injury. The Lancet 2020;395:473-5 https://doi.org/10.1016/S0140-6736(20)30317-2

64. Rokni M, Ghasemi V, Tavakoli Z. Immune responses and pathogenesis of SARS-CoV-2 during an outbreak in Iran: Comparison with SARS and MERS. Rev Med Virol 2020;30(3):e2107. https://doi.org/10.1002/rmv.2107

65. Zimmermann $\mathrm{P}$, Curtis N. Coronavirus Infections in Children Including COVID-19. Pediatr Infect Dis J 2020;20:00 https://doi.org/10.1097/INF.0000000000002660

66. Zheng F, Liao C, Fan Q-h, et al. Clinical characteristics of children with coronavirus disease 2019 in Hubei, China. Curr Med Sci 2020:1-6

67. Horby P, Lim WS, Emberson JR, et al. Dexamethasone in Hospitalized Patients with Covid-19. N Engl J Med 2021;384:693-704. https://doi.org/10.1056/NEJMoa2021436

68. Matthay MA, Thompson BT. Dexamethasone in hospitalised patients with COVID-19: addressing uncertainties. Lancet Respir Med 2020;8:1170-2. https://doi.org/10.1016/S2213-2600(20)30503-8 


\title{
Opsežan pregled lečenja COVID-19
}

\author{
Zeinab Mohseni Afshar1, Arefeh Babazadeh², Mostafa Javanian², Mohammad Barary33, \\ Veneela Krishna Rekha Vasigala ${ }^{4}$, Soheil Ebrahimpour ${ }^{2}$
}

\author{
${ }^{1}$ Kliničko-istraživački centar za razvoj, Bolnica Imam Reza, Univerzitet medicinskih nauka u Kermanšahu, \\ Kermanšah, Iran \\ 2Istraživački centar za infektivne i tropske bolesti, Zdravstveni istraživački institut, \\ Univerzitet madicinskih nauka u Babolu, Babol, Iran \\ ${ }^{3}$ Studentski istraživački komitet, Univerzitet medicinskih nauka uBabolu, Babol, Iran \\ ${ }^{4}$ Medicinski koledž Rangaraya, Univerzitet zdravstvenih nauka NTR, Kakinada, Indija
}

\section{SAŽETAK}

Ozbiljan akutni respiratorni sindrom korona virusa 2 (SARS-CoV-2) je oboljenje virusa koje je 2019. godine izazvao virus COVID-19. Ovaj novi korona virus postaje sve veća globalna pretnja po javno zdravlje. Do 18. aprila 2021. godine, potvrđeno je 140 miliona inficiranih slučajeva i 3 miliona smrtnih slučajeva. Premda su dva leka odobrena za lečenje ove bolesti, remdesivir i deksametazon, brojne studije su u toku kako bi se ispitale nove terapijske opcije. Međutim, do sada, mnoge terapije bile su pomoćne i klinička efikasnost tih lekova još uvek se ispituje. Cilj ovog preglednog rada je sumiranje trenutnih načina lečenja, poput primene nekoliko antivirusnih lekova, transfuzije plazme rekonvalescenata, pomoćnih lekova sa namerom formiranja kliničkog vodiča za lekare i resursa za buduće evaluacije u različitim kliničkim ispitivanjima.

Ključne reči: COVID-19, SARS-CoV-2, terapeutici, antivirusni lekovi, COVID-19 seroterapija 